\title{
TRANSFORMATIVE LEGAL EDUCATION IN THE SOUTH AFRICAN CONTEXT
}

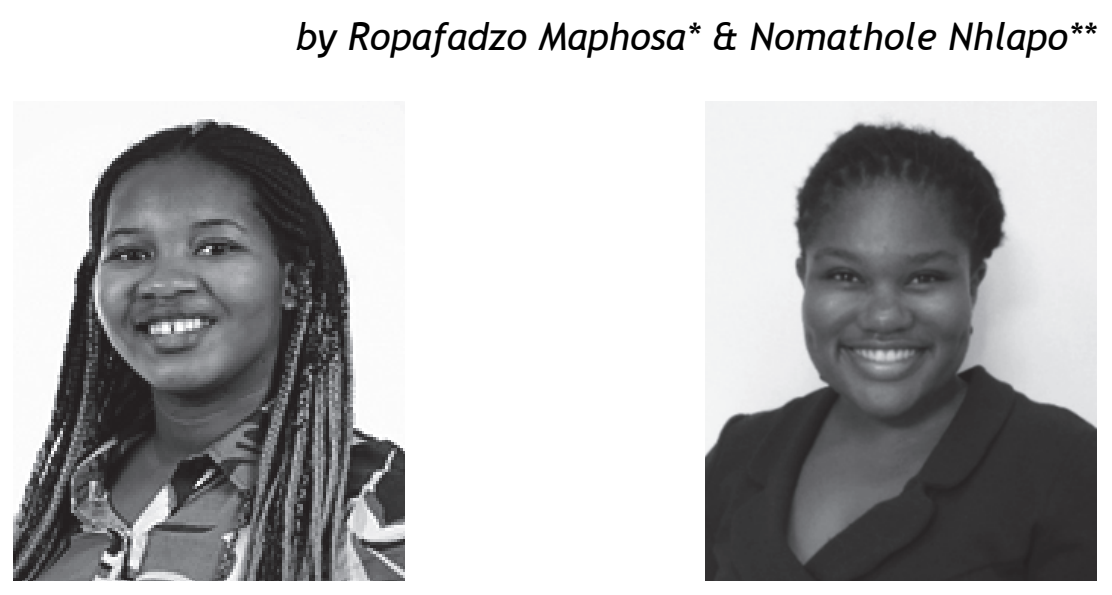

Abstract:

The late former Justice of the Constitutional Court of the Republic of South Africa, Pius Langa, opined that a truly transformative South Africa requires a new approach that places the Constitutional dream at the very heart of legal education. This view is consistent with section 29 of the Constitution which guarantees everyone the right to further education. However, the state has failed to make further (or tertiary) education progressively available and accessible. We believe this can be attributed to the fact that the South African legal education is still riddled with inequalities from the apartheid/colonial era. This article argues that decolonisation of legal education will begin when teachers of the law become cognizant of the reality that their teaching models will shape the future legal landscape, thus it is imperative for law schools to birth law graduates with an unwavering appreciation and willingness to implement constitutional values, such as human dignity and equality in practice. The advancement of these values is enhanced by the Africanisation of legal education which will ultimately legitimize the legal order so that it mirrors the society in which it exists.

* Ropafadzo Maphosa (Researcher at the South African Institute for Advanced Constitutional, Public, Human Rights and International Law (SAIFAC)). She holds an LLM degree from the University of Johannesburg. E-mail: ropamaphosa@gmail.com.

** Nomathole Nhlapo (Candidate Attorney at Cliffe, Dekker and Hofmeyr (CDH)) She holds an LLB degree from the University of Johannesburg. E-mail: nomathole.nhlapo30@gmail.com. 
Secondly, the transformation of the colonial system of education requires that we regard law as part of the social fabric and law students are encouraged to view it as such. Transformative constitutionalism requires that students not only see the law as an instrument that was used to oppress in the past, but as a greatly influential tool with an unfettered capacity to transform our society. An important facet of transformative constitutionalism lies in improving the quality of education through a better understanding of the process of teaching and learning. This article concludes with a call for the sweeping redesign of legal education in South Africa, including an overhaul of the pedagogy of apartheid and colonialism with special emphasis on the leveling of educational inequalities which were dramatically skewed during the apartheid era.

Key Words: Transformative legal education, transformative constitutionalism, pedagogy

\section{Introduction}

Aristotle said, 'the ultimate goal of education is to assist human beings in developing their unique capacity to contemplate the world and their role in it'. 'For historically disadvantaged students, this goal has not been realised due to the remnants of the apartheid legal system that continue to linger more than 25 years later. This article discusses how a shift in pedagogy of legal education and the inclusion of African customary law can address systemic obstacles to the attainment of transformative legal education. For the purpose of this article, legal education refers to a curriculum which equips law students for filling different roles in society, and for various law related careers. ${ }^{2}$ Therefore, the terms 'legal education' and 'curriculum' will be used interchangeably.

The first segment begins with a review of legal education in the Apartheid era considering the separation of educational institutions based on race. In the second section, the authors will assess how the previous education system has shaped the current state of legal education in South Africa in light of the post-Apartheid LLB degree. This article will then address the pedagogy of legal education, more particularly its failure to integrate customary law into the current LLB curriculum. Finally, this article concludes with a re-examination of legal education in the African context and a call for the teaching of legal education through a therapeutic lens with a suffusion of the notions of transformative constitutionalism and ubuntu.

$1 \quad$ TW Johnson and R Reed Philosophical documents in education (2000) 35.

2 A Lakshminath 'Legal education, research and pedagogy' (2008) 50 (4) Journal of the Indian Law Institute 606. 


\section{Legal education in the colonial/apartheid era}

The colonial system and Apartheid created much division between the state judiciary and the traditional chief tribunals that were exclusively used for the resolution of legal disputes between the black communities. ${ }^{3}$ The alienation of customary law from its indigenous origins began with the colonial policy of indirect rule when indigenous legal regimes were co-opted to the received systems of European law. ${ }^{4}$ As a result, the division played a critical role in the way in which legal education was taught in universities during both the colonial and the Apartheid era.

The history of South African law is framed as a Roman-Dutch system, influenced by English law, without much attention given to African law. Roman-Dutch law principles ('the common law') have remained in areas of the law such as property law, contracts and wills because these were strongly grounded in equitable principles and supported by an adequate availability of authoritative text sources both in Latin and Dutch. ${ }^{5}$ When the British assumed control over the colony in 1806, many aspects of English Law were adopted which shaped the existing South African procedural law and all branches of commercial law, such as insurance law, maritime law and company law. English Law supplemented the deficiencies and gaps that had arisen in the law as it developed at the Cape. ${ }^{6}$

Prior to the new constitutional dispensation in South Africa, legal education was largely characterised by racial disparity. There are various ways in which legal education either bolstered apartheid or was influenced by it. For instance, those in positions of influence used it to regulate access to the legal professions to ensure that the pattern of white domination in the field would persist. ${ }^{7}$ This access was reinforced by apartheid governmental policy through the limited participation of minorities in political and legal processes and through a lack of educational and employment opportunities. ${ }^{8}$

3 M Ndulo 'Legal education in Africa in the era of globalization and structural adjustment' (2002) 20 Penn State International Law Review 487.

4 T Bennett 'The compatibility of African Customary Law and human rights' (1991) 1 Acta Juridica 18.

5 L Greenbaum 'A history of the racial disparities in legal education in South Africa' (2009) 3 (1) John Marshall Law Journal 6.

6 As above.

7 Bantu Education Act 47 of 1953; Extension of University Education Act 45 of 1959.

8 Greenbaum (n 5 above) 7. 


\subsection{A lack of resources: A challenge at historically black universities}

Legal education reflected the apartheid system of allocation of national resources along racial lines. ${ }^{9}$ Separate education, including university education, was provided to students based on their racial designation, with separate institutions established for white, black, Indian and coloured persons. This was facilitated by the Bantu Education Act and the Extension of University Education Act, ${ }^{10}$ which empowered the government to establish universities for black people and ensured that 'white' universities were closed to black students. ${ }^{11}$ In its report, the Commission on Native Education highlighted that the black community received limited funds which ensured minimum educational effect. ${ }^{12}$ After the establishment of separate university colleges, the 'historically black universities' (HBUs) remained underresourced and inconveniently located in rural areas so as to ensure that the quality of the education provided was not comparable to that offered at generally historically white institutions (HWUs). ${ }^{13}$ This separation perpetuated the stereotype that degrees conferred from HWUs were of a higher calibre compared to those obtained from HBUs. This had a negative impact on the ability of graduates from HBUs to obtain employment in top law firms. ${ }^{14}$

Prior to 1995 , the statutory requirement for all practising lawyers to have passed a university course in English, Afrikaans and Latin remained an impediment to black candidates. ${ }^{15}$ Furthermore, the obstacles in gaining access to high quality tertiary education; the cost and the length of time required to obtain an LLB degree to qualify as an advocate coupled with the difficulty of obtaining articles of clerkship in urban white male-dominated law firms, ensured that black lawyers were effectively restricted to the lower levels of practice within the legal profession. Even in the event that they were successful in overcoming the many structural barriers within the differentiated education and legal systems, black law graduates faced restrictions in the geographical areas where they could practise. ${ }^{16}$ This resulted in that branch of the profession being dominated by white practitioners and appointment as a judge could only be made

9 JB Kaburise 'The structure of legal education in South Africa' (2001) 3 Journal of Legal Education 364

10 Extension of University Education Act 45 of 1959.

$11 \mathrm{~J}$ Moulder 'Academic freedom and the Extension of University Education Act' (1975) (1) Philosophical Papers 64

12 Report of the Commission on Native Education (Eiselen Commission) 1949-1951, Government Printer, 1953.

13 Greenbaum (n 5 above) 10

14 Greenbaum (n 5 above) 10.

15 L Greenbaum 'The four-year undergraduate LLB: Progress and pitfalls' (2010) 35 (1) Journal of Juridical Science 2.

16 Greenbaum (n 5 above) 13. 
from the ranks of experienced advocates thus reinforcing the discriminatory effect that the differential qualifications had in terms of racial, gender and socio-economic bias.

Since 1994, more black law students have attended law schools and many of them come from modest economic backgrounds. Even with the possibility of entering into well-paying employment in the private sector and government, many come to these positions with limited financial resources, debt and sizable family obligations and responsibilities. This makes it difficult for most African graduates to complete a full year of pupillage without compensation.

In practice, the apartheid government policies of having separate trade areas for each racial group enacted by the Group Areas Act ensured the geographical isolation of black practitioners due to the restrictions which placed their practice areas in 'townships' or black 'homelands'. ${ }^{17}$ This policy was not based on the notion of justice, and it had an effect on our approach to the law. ${ }^{18}$ As a result, our legal education was riddled with contradictions, anomalies and inconsistencies.

Although the South African government has established the National Student Financial Aid Scheme (NSFAS) to 'redress past discrimination and ensure representation and equal access ... and establish an expanded national student financial aid scheme that is affordable and sustainable', ${ }^{19}$ the scheme has several pitfalls which have left many students at a disadvantage. ${ }^{20}$ Since its inception, the NSFAS has grown considerably in terms of the amount of money available for annual disbursement. However, despite the significant increase in government funding allocated to the NSFAS, the demands on the scheme continue to exceed available resources. NSFAS currently assists about 17 percent of higher education students, but estimates show that NSFAS only has half of the funds it would need to meet the demand for student financial aid from qualifying applicants. ${ }^{21}$ It is evident that the scheme is not able to fund all current awardees at the levels required to fully meet their tuition and living expenses. Moreover, while students can now use their NSFAS loans to pay their registration fees, the way this process is handled by institutions is neither consistent nor uniform. A number of institutions still insist that students pay registration fees, despite the NSFAS provision.

17 Group Areas Act 41 of 1950. Black Lawyers

Association

(BLA)

18 Greenbaum (n 5 above) 13.

19 National Student Financial Aid Scheme Act 56 of 1999.

20 Preamble of the National Student Financial Aid Scheme Act.

21 Ministerial Committee 'Report of the ministerial committee on the review of the National Student Financial Aid Scheme (NSFAS)' 200973. 
In HBUs such as the University of Fort Hare, Walter Sisulu University and University of Limpopo, where demand far outstrips supply, there is often a spread of the NSFAS allocation to as many students as possible by granting smaller awards to a larger number of students, in order to provide a temporary solution to the dilemma of financial exclusion. ${ }^{22}$ University administrators do not take into account that allocating funds on a 'some for all' instead of an 'all for some' basis results in all students being substantially underfunded. Such underfunding impedes students' chances of succeeding. It is a cruel irony that the use of NSFAS loans to inadequately fund many students contributes to a high dropout and failure rate among the very group for whom the scheme was set up to provide access to higher education. This is precisely the 'revolving door' outcome against which the White Paper: A Programme for the Transformation of Higher Education warned in 1997:

Poor students gaining access to the higher education system education system, but being unable to complete their studies, so being 'revolved' back into poverty - in this case with the additional burden of a student loan debt - including unfunded institutional debt - they are unable to repay because they lack the qualifications to secure formal employment. ${ }^{23}$

Another pitfall of NSFAS is that prior to 2018, funding was limited to students whose family income was less than R122 000 per annum. ${ }^{24} \mathrm{At}$ present, the threshold of R350 000 family income per annum now applies to students who were first-time entrants in 2018 and will also apply to first time-entering students in 2019 going forward. ${ }^{25}$ There are many households above the R350 000 per annum joint income threshold that require financial assistance; these are the so-called 'missing middle' in the current student financing arrangement. Despite being disqualified from NSFAS funding because their incomes are too high, these families cannot afford to fund their children's higher education themselves, especially if more than one child wants to study at the same time. In the light of this, the NSFAS has not been able to extend its reach to the increasing numbers of students whose family income is above the NSFAS eligibility threshold but who cannot afford to access higher education without financial aid. ${ }^{26}$

22 Ministerial Committee Report (n 21 above) 39.

23 Ministerial Committee Report (n 21 above) 39. See also N Cloete 'For sustainable funding and fees, the undergraduate system in South Africa must be restructured' South African Journal of Science (2016) 112 (3/4) 4.

24 Ministerial Committee Report (n 21 above) 63.

25 Ministerial Committee Report (n 21 above) 37.

26 South African Union of Students Submission to the Ministerial Review Committee, August 2009 in Ministerial Committee Report 65-67. 


\subsection{The current state of legal education in South Africa}

The legacy of the previous inequalities discussed above continues to linger in the current legal education system, replicating a cycle of disadvantage that is reflected in poor student graduation rates amongst black students and high student attrition rates. ${ }^{27}$ With the transition to democracy in 1994, the need to address the underrepresentation of historically disadvantaged people in all areas of the legal profession and to establish a single, affordable academic qualification was undeniable. A commitment to incorporate the teaching of legal skills and ethical values, and to heighten students' sensitivity to diversity, formed part of the proposal by the curriculum Task Team of Law Deans and professional representatives in 1996. ${ }^{28}$

In 1995, the South African Ministry of Justice convened a Legal Forum on Legal Education for the purpose of critically reviewing the structure and provision of legal education, with a view to devising a new system that would give expression to the new constitutional dispensation in the country. ${ }^{29}$ Emerging prominently at the forum was a general consensus that the approach to legal education in South Africa needed change. A dominant theme in this respect was the structure of the basic law degree, together with the need to design a form of legal education which would include both formal academic and practical skills training. ${ }^{30}$ Consensus was reached that a standard legal qualification lasting four years, followed by one year of practical training, should be adopted as the norm by all South African law schools. The degree was designated as the undergraduate LLB, and the first intake of students for the new degree began in the 1998 academic year. ${ }^{31}$

The four-year LLB programme was introduced in South African universities in 1998 through the Qualification of Legal Practitioners Amendment Act 78 of 1997 as an alternative measure of the five-year LLB, in order to create a shorter and less expensive way for LLB students to obtain their law degree. ${ }^{32}$ The justification for the introduction of the four-year LLB programme was twofold: firstly, there were too few black South Africans represented in the legal profession; and, secondly, the country's previous apartheid laws, i.e. the Extension of University Education Act, had resulted in a

27 Greenbaum (n 5 above) 1.

28 Proposals by the Task Group on the Restructuring of Legal Education (1996) 11 in Greenbaum (n 15 above) 10.

29 Ministry of Justice, Proceedings of the Legal Forum on Legal Education (1995) 96 in Greenbaum (n 15) 9.

30 Kaburise (n 9 above) 366.

31 As above.

32 ES Fourie "Constitutional values, therapeutic jurisprudence and legal education in South Africa: Shaping our legal order' (2016) 19 (1) Potchefstroom Electronic Law Journal 8. 
distinction between the various law degrees that were obtained by black and white students. ${ }^{33}$ Prior to 1997, law graduates held either a B Proc degree or a postgraduate LLB after completing a primary degree. ${ }^{34}$ The expense of completing two degrees and the additional years spent studying at university represented an impediment that most aspiring African lawyers were unable to afford. In an effort to redress these imbalances, the Government introduced a single law degree, which was intended to remedy both the problem of underrepresentation as well as to provide equal qualifications for all.

While the convergence of a plethora of factors inevitably led to a theatrical re-conceptualisation of legal education in 1996, little attention was paid to the pedagogic soundness of the change. ${ }^{35}$ On the surface, the government succeeded in remedying the problem with which it was faced: the new LLB did produce more black law graduates. However, 'the informing vision that inspired the change appears to have been founded upon unarticulated premises, lacking in a well-researched or pedagogical foundation'.36

\subsection{The expectations of the legal fraternity from law students}

Law firms and the legal profession at large have noted that law students are not prepared for the legal profession with a 4-year LLB because law students lack maturity, numeracy skills, literary skills and critical thinking amongst other prerequisites for legal practice. ${ }^{37}$ This is problematic because poorly literate candidate attorneys and lawyers may fail in their duty to advance the interests of the client and ultimately reduce the public's faith in the legal system in the long term if lawyers are unable to perform effectively. ${ }^{38}$

There are expectations from the general public and within the legal profession itself as to how legal practitioners should conduct themselves in the profession. A higher ethical standard is placed on the legal profession because of the esteemed and well-respected nature of the legal profession. The legacy of the LLB curriculum has left many wondering whether LLB graduates are ' $f$ it and proper' for practice as per section 24(c) of the Legal Practice Act (LPA), which provides that a legal professional is admitted if he or she is a fit and proper person. ${ }^{39}$ 
The LPA brought about a new dispensation within the South African legal system, however, the founding principles for the admission of advocates and attorneys have since remained the same. ${ }^{40}$ The Act does not define the 'fit and proper' requirement extensively. However, in the legal field, it is commonly accepted that the meaning of a 'fit and proper' person include characteristics as 'complete honesty, reliability and integrity'. ${ }^{41}$ In Prokureursorde van Transvaal $v$ Kleynhans, ${ }^{42}$ the question before the court related to the constitutionality of the judiciary to remove 'unfit and improper' persons from the roll of attorneys. The court held that 'standards could be set for the legal profession as far as both "competence" and "unquestionable integrity" were concerned'. 43 In addition to the requirements of competence and knowledge of the law, the overarching principle for one to be 'fit and proper' is the possession of integrity which is essential in the legal profession. According to the Law Society of South Africa, the requirement of a fit and proper person refers to the moral integrity of a person. ${ }^{44}$ To this end, the Legal Practice Council was established to protect and promote integrity in the legal profession, and to protect the interests of the client in the context of the relationship between the lawyer and the client. ${ }^{45}$

It is apparent from the above discussion that ethical standards should be emphasised in the foundational years of legal education, in order to prepare students for practice. In terms of section 195(1)(a) of the Constitution of the Republic of South Africa, 1996 (the Constitution), public administration must be governed by the values of the Constitution, thus, a high degree of professional ethics must be maintained. ${ }^{46}$ Moreover, public administration applies to every sphere of government including the judiciary. ${ }^{47}$ Therefore, it is imperative for the ethics of the legal profession to be emphasised in legal education, in order to achieve transformative legal education and lawyers who are fully aware of their duties.

\subsection{Alternatives to the LLB curriculum}

Dissatisfaction amongst stakeholders regarding the quality of law graduates has added to the current impasse as to how legal education can most effectively be improved. Two alternatives have been

40 Admission of Advocates Act 74 1964; Attorneys Act 53 of 1979.

41 General Council of the Bar of South Africa $v$ Geach and others 2013 (2) SA 52 (SCA) para 126.

42 Prokureursorde van Transvaal v Kleynhans 1995 (1) SA 839 (T).

43 As above.

44 'Methods for qualification' http://www.lssa.org.za/about-us/about-the-attor neys-profession/becoming-an-attorney (accessed 27 February 2019).

45 Section 5 of the LPA.

46 Section 195(1) (a) of the Constitution.

47 Section 195(2) (a) of the Constitution. 
suggested for remedying the deficiencies of the current four-year LLB. The first is an extension of the four-year programme and will be similar to what some universities already offer to 'at risk' students. ${ }^{48}$ The University of the Western Cape, for example, offers an extended programme which includes a foundation year where students acquire various numeracy and literary skills to assist them in their transition to legal studies.

The second is a return to the postgraduate LLB which is still offered by some institutions that opted to retain the postgraduate degree when they first introduced the four-year curriculum, for example the University of Witwatersrand. Suggestions to extent the duration for the attainment of a LLB qualification from the current minimum four years of study to a minimum of five years of study have been made. Of the two alternatives mentioned, the first option seems more practical as it only requires students to register for one degree instead of two. The authors are of the opinion that extending the current undergraduate LLB by one year will not provide much of a solution to the problems currently experienced. Given the criticisms that have been raised, the central issue clearly concerns the curriculum and its failure to meet the demands of practice.

Curriculum issues are unsurprising given the fact that each university was allowed academic freedom regarding the content of the current four-year LLB degree. To this end, the Council on Higher Education ( $\mathrm{CHE}$ ) has urged many institutions where the LLB is taught to reform the curriculum. ${ }^{49}$ The primary consideration in this report is that programmes have to be aligned with principles of transformative constitutionalism. Perhaps if 'core courses, practical skills training or non-law courses for inclusion in the curricula' had been identified from the outset instead of a mere 'list of recommended core subjects', legal education would be in a much better position today. ${ }^{50}$

It is evident that the notion of academic freedom, which was strongly advocated by the Task Group on Legal Education, and which permitted individual faculties to interpret the degree requirements as they saw fit, was ill-placed. The proposals did not identify practical skills training or non-law courses for inclusion in curricula, leaving these choices to individual faculties as a matter of preserving their autonomy. ${ }^{5}$

However, the Council of Higher Education recommended that it is necessary to set the Qualification Standard for Bachelor of Laws (LLB)

48 Van Niekerk (n 38 above) 539.

49 Council on Higher Education 'The state of the provision of the Bachelor of Laws (LLB) qualification in South Africa' 2018.

50 Greenbaum (n 15 above) 10.

51 Van Niekerk (n 38 above) 540. 
to allow quality assurance of higher education qualifications as prescribed by the National Qualifications Framework Act 67 of 2008 and the Higher Education Qualifications Sub-Framework. ${ }^{52}$ To ensure optimal adherence to the specific qualification standards developed for the Bachelor of Laws degree in 2015, the extended LLB may provide the answer - provided that it is applied uniformly at all institutions offering an LLB degree. This will also go a long way in ironing out prejudices in the law fraternity that law graduates from certain universities are of a higher caliber than others, thus making them more marketable. ${ }^{53}$

As it stands, with students struggling to complete the four-year degree in record time, it seems improbable that a return to the postgraduate LLB would make students better equipped to complete a second degree. Regardless of the option of pursuing a second degree being available to all, the reality in this country is that it would only be utilised by an elite who are in a financial position to do so. This factor takes one right back to where it all started, when the four-year LLB was considered the only solution to address the socio-economic inequalities of the past. ${ }^{54}$

Despite promises by the post-1994 democratically elected government to redress the historical inequity of the HBUs, the reality is that their goals have not been met. HWUs continue to have better facilities and more resources which attract more students and more state funding because state subsidies are linked to students enrolment numbers. Their superior facilities make them more attractive to students and academic staff alike. ${ }^{55}$ Many of the historically disadvantaged institutions continue to be plagued by the structural legacies inherited from the apartheid education system. Although HBUs such as the University of Fort Hare were often the site of resistance to the apartheid regime and the focus of political opposition to the Nationalist government, since 1994, their appeal to black students and staff has diminished as they have not been able to meet the new imperatives of skills development, quality research production and creating improved facilities. ${ }^{56}$

There are also discrepancies in the resourcing of the HWUs and the HBUs. ${ }^{57}$ The student-staff ratio is generally much higher at the HBUs. Library resources at HBUs do not compare at all with those at HWUs. Academic support programmes at HBUs are often inadequate

52 The Higher Education Qualifications Sub-Framework (HEQSF) (2013). See further the Council on Higher Education (CHE) Qualification Standards for the Bachelor of Laws (April 2015).

53 Van Niekerk (n 38 above) 534

54 Van Niekerk (n 38 above) 541.

55 Greenbaum (n 5 above) 12.

56 As above.

57 Kaburise (n 9 above) 365. 
compared to support programmes at HWUs. Administrative support at HBUs does not compare well with that at HWUs. ${ }^{58}$ The above points are the direct result of the state's financial under-resourcing of the HBUs for the past decades. As a result, HBUs are underfinanced and are mostly located in non-metropolitan areas, and find it difficult to attract and to retain well-qualified and experienced staff.

\section{The pedagogy of legal education in South Africa}

The curriculum overemphasises corporate and private-practice courses, partly in response to student perceptions about their employability to the detriment of courses focusing on crucial social issues. ${ }^{59}$ Consequently, African customary law is often taught as a detached course, instead of being woven into the substance of doctrinal courses. ${ }^{60}$ Himonga and Diallo suggest that there are three elements to the decolonisation of the law and legal education which are the following: (a) the inclusion of living customary law in legal education; (b) the shift in the way in which the law is taught at universities; and (c) the interdisciplinary study of the law. ${ }^{61}$ The three elements are discussed below.

\subsection{The inclusion of living customary law in legal education}

Prior to the constitutional dispensation, customary law seldom attracted much attention in South Africa; in Bennett's view, it was a Cinderella subject. ${ }^{62}$ This was a deliberate policy to exclude Africans and their institutions from the mainstream of South African law. ${ }^{63}$ The alienation of customary law from its community origins began with the colonial policy of indirect rule when indigenous legal regimes were co-opted to the received systems of European law. However, the status of customary law in South Africa is now constitutionally protected in section 211 of the Constitution which provides that the institution, status, and role of traditional leadership are recognized subject to the constitution. It further states, 'courts must apply

58 As above.

59 B.R Henderson 'Asking the lost question: What is the purpose of law school?' (2003) 53 Journal of Legal Education 48.

60 L Greenbaum 'Legal education in South Africa: Harmonizing the aspirations of transformative constitutionalism with our educational legacy' (2015) New York Law School Law Review 480.

61 C Himonga \& F Diallo 'Decolonisation and teaching law in africa with special reference to living customary law' (2017) 20 Potchefstroom Electronic Law Journal 7.

62 Bennett (n 4 above) 18.

63 As above. 
customary law when that law is applicable, subject to the Constitution and [relevant] legislation ...'.

The courts have made progress to develop and ensure the recognition of customary law in South Africa. In Alexkor $v$ Richtersveld Community, ${ }^{64}$ the Constitutional Court found that customary law must be recognised as an 'integral part' of the law and 'an independent source of norms within the legal system'. This was echoed by Van der Westerhuizen J in Shulubana $v$ Nwamitwa wherein he explained that the status of customary law requires respect. ${ }^{65}$ In addition, Langa DCJ (as he was then) noted in Bhe $v$ Magistrate, Khayelitsha that an approach that disregards the rules or provisions of customary law on the basis that such rules are different from the common law or legislation would be incorrect. ${ }^{66}$

Nhlapo submits that when the court makes reference to customary law, it is specifically referring to living customary law. ${ }^{67}$ Living customary law alludes to the unwritten traditions and laws of each ethic group whether recognised by the state or not. Moreover, living customary law refers to the traditional practices that are accepted by its people as binding authority. ${ }^{68}$ As a result, this allows for living customary law to be flexible and adapt to the needs of society. It is important for the laws of South Africa to adapt to the changing needs of society, to move away from colonial laws and create laws that are relevant to South African issues. Diallo and Himonga argue that legal education is the most appropriate platform to dissect the intricacies of living customary law and for law students to fully understand the role living customary law can play in the creation of laws in South Africa. ${ }^{69}$

Additionally, the shift in the way in which laws are taught is imperative to the introduction of the Africanisation of legal education. For the purposes of this article, we interpret Africanisation as the infusion of indigenous knowledge and concepts into the law curriculum. Living customary law is still not the preferred solution to solving customary law issues. However, judges and legal professionals still 'view living customary law as non-existent, or regard living customary law as informal law that is irrelevant to State institutions'.70 Universities choose different ways of teaching customary law in their law schools, either as a semester module or year module. The authors submit that customary law should be

64 Alexkor v Richtersveld Community 2004 (5) SA 460 (CC) para 50.

65 Shilubana and others $v$ Nwamitwa 2009 (2) SA 66 (CC) para 69.

66 Bhe and others $v$ Khayelitsha Magistrate and others 2005 (1) SA 580 (CC) para 42.

67 T Nhlapo 'Indigenous law and gender in South Africa: Taking human rights and cultural diversity seriously’ (1994 volume 13 Article 1 Third World Legal Studies 53.

68 Bennet (n 4 above) 18.

69 Diallo \& Himonga (n 61 above) 7.

70 Greenbaum (n 60 above) 11. 
incorporated in different modules in order to ascertain how customary rules would solve legal issues, such as those relating to property law, succession, and dispute resolution with respect to family law matters.

\subsection{A shift in the pedagogy of legal education}

The law is subject to the pressure of social change, with each age making new and different demands upon the legal practitioner, and teachers of law must pay attention to these ever-changing demands. ${ }^{71}$ Upon a reflection of societal changes, immediate issues arise concerning the system of legal education in South Africa. ${ }^{72}$ The most pertinent one is whether our law faculties provide students with an adequate awareness on the social processes operating in society. Secondly, it is uncertain whether students are adequately equipped to be able to push back the frontiers of legal knowledge and to make a tangible and constructive contribution to society in the field in which they have been trained. ${ }^{73}$

John Dugard criticised legal education in South Africa for its failure to relate law to the social sciences; and the general lack of interest among lawyers in the nature and role of law in modern South African society. ${ }^{74}$ The authors share the same views and submit that the approach to our legal education is too compartimentalised. As noted by Klare that despite the 'substantively post-liberal and transformative aspirations' of our Constitution, our legal culture is still a highly conservative one, meaning that South African lawyers instinctively rely on a legal methodology that places relatively strong faith in the precision, determinacy and self-revelation of words and texts and that interpretation of such legal texts is "highly structured, technical, literal and rule-bound' with little emphasis on values and policy. ${ }^{75}$ There is far too little critical examination of much of the underlying bias of the law. ${ }^{76}$ Fundamental concepts, such as freedom of testation, freedom of contract and even the rule of law, are too often treated axiomatically rather than subjected to critical examination. 77

71 CC Turpin 'Legal education in South Africa' (1958) Acta Juridica 154.

72 R Henrico 'Educating South African legal practitioners: combining transformative legal education with ubuntu' (2016) volume 13 US-China Law Review 838

73 DM Davis 'Legal education in South Africa: A re-examination' (1978) South African Law Journal 425.

74 J Dugard 'The judicial process, positivism and civil liberty' (1971) 88 South African Law Journal 181 at 185.

75 KE Klare 'Legal culture and transformative constitutionalism' (1998) 14 (1) South African Journal of Human Rights at 146.

76 As above.

77 Davis (n 73 above) 426. 
As a rule the only theoretical economic and philosophical examination of the law and legal system takes place within one specific jurisprudence course, yet a critical socio-economic and jurisprudential examination of the branches of substantive law is mostly ignored. ${ }^{78}$ This positivistic approach to legal education has resulted in the curtailment of legal thought and literature on the vital question of the very framework of the law and legal system; this has had a detrimental practical effect on the legal profession. ${ }^{79}$

Turpin is of the view that if an important object of legal education is to produce practitioners who are 'officers of civilization', the teaching of law should be scientific or theoretical as well as practical. ${ }^{80}$ He explains that the difference between a scientific and a practical teaching of law is to a great extent one of selection of the material to be taught. ${ }^{81}$ A purely practical legal education aims to provide knowledge of rules necessary to be known in practice, and skill in their application, but not more. A scientific legal education aims to provide material bearing on law, which are not necessarily legal in nature, but illuminate rules of law. It is necessary to consider the elements of a sound scientific legal education, and thereafter to return to a consideration of the practical aims which legal education should pursue. ${ }^{82}$ An example of tools that can be used to achieve this is an emphasis on moot court competitions which is a form of practical legal education. Such competitions enhance students' oral and research skills.

\subsection{The inter-disciplinary study of the law}

Lastly, law must be presented not as a collection of distinct branches, each existing within its own silo, but in an integrated fashion that reveals the connections among the various branches, especially in relation to the shared normative value system that underlies it all flowing from the Constitution. ${ }^{83}$ The interdisciplinary teaching of law allows for the relationship between the law and the practices of society. It is essential for the laws of the country to reflect the social and economic problems that arise in society and for the law to address these issues effectively. Disciplines outside of the law such as sociology, history and anthropology can assist in the understanding and the interpretation of law for the issues of society to be understood in an African context. ${ }^{84}$ Additionally, emphasis on the

79 As above.

80 Turpin (n 71 above) 154.

81 As above.

82 As above.

83 G Quinot 'Transformative legal education' (2012) 129 (3) South African Law Journal 416.

84 Nhlapo (n 67 above) 14. 
integration of law with other disciplines will ensure that law students are equipped with skills to engage in the substantive mode of reasoning required within the scaffold of transformative constitutionalism. 85

A comparative study of other legal systems may also be used as a tool to encourage law students to have a constructively critical attitude towards South African law, as well as a fuller appreciation of its merits. ${ }^{86}$ As aforementioned, the law is not a self-contained system of norms isolated from experience and developments in other fields. While for some the proper and complete object of study for the lawyer is law, for others this would not suffice and they recommend a policy-directed legal education that assists the student to observe the law in a broader context. ${ }^{87}$

\section{Re-examination of legal education in the African context}

Decolonisation in a general sense does not mean that Africa should return to the system that existed before colonisation - this would be impractical due to globalisation and the growing pace of the world. However, Himonga and Diallo explain that decolonisation in the legal context means drawing from different sources of law and normative agencies to promote the transformative potential of law in achieving more social and economic justice. ${ }^{88}$ As a result, the aim of decolonisation is to ensure the transition from the laws of apartheid and colonial principles to an era mindful and embracive of African legal cultures. ${ }^{89}$

\subsection{Constitutional values reflected in legal education}

The social, political, economic and legal advancement of mankind is attributed to the accomplishments of various role-players, including those of our legal practitioners and their educators. ${ }^{90}$ Thus, it is vital for law schools to be conscious of their responsibility to remind law scholars that by studying law they have the power to transform thoughts, policies and lives, and that the greatest reward of practising law is contributing to the betterment of society and ultimately to 
social change. ${ }^{91}$ In 2009, the South African Law Deans Association (SALDA) and the Society of Law Teachers of Southern Africa (SLTSA) re-affirmed their 'responsibility to produce lawyers with the necessary analytical skills, critical disposition and independence of thought to play a meaningful role in the development of [South African] society' and called on 'all legal educators and stakeholders to exert their energies to achieve this'. ${ }^{92}$

The imperative is to implement the tenets of transformative constitutionalism to bring about a change in the life of others in accordance with the values and ethos of the Constitution. ${ }^{93}$ It is on this premise that Fourie and Coetzee assert that the introduction of concepts such as 'therapeutic jurisprudence' enhanced by important constitutional values, such as human dignity and ubuntu, into skills courses and clinical education is a means of ensuring that future legal practitioners may be responsible agents of social change. ${ }^{94}$ Therapeutic jurisprudence focuses on the law's impact on emotional life and psychological well-being. ${ }^{95}$ It is a perspective that regards the law (rules of law, legal procedures, and roles of legal actors) itself as a social force that often produces therapeutic or anti-therapeutic consequences ...' 96 Hence, Henrico argues that the realisation of social justice by means of a comity between transformative legal education (TLE) and ubuntu is necessary to advance the interests of the less privileged, the marginalised and generally assist others who would not otherwise have a voice or opportunity. ${ }^{97}$

The constitutional imperative of access to justice for all underlies the importance for law lecturers to incorporate therapeutic jurisprudence in their teaching methods from their first year until the completion of the students' studies. Therapeutic outcomes achieved by teaching through a therapeutic lens contribute to the national goal of improving access to justice. ${ }^{98}$

For instance, property law lecturers can emphasise the antitherapeutic consequences of the law in South Africa. In President of the Republic of South Africa $v$ Modderklip Boerdery, ${ }^{99}$ the Constitutional Court developed the common law principle of rei

91 E Fourie \& E Coetzee 'The use of a therapeutic jurisprudence approach to the teaching and learning of law to a new generation of law students in South Africa' (2012) 15(1) Potchefstroom Electronic Law Journal 367.

92 W Freedman and N Whitear-Nel 'A historical overview of the development of the post-apartheid South African LLB degree- with particular reference to legal ethics' (2015) 21 (2) Fundamina 237.

93 Henrico (n 72 above) 825.

94 Fourie \& Coetzee (n 91 above) 1.

95 Fourie \& Coetzee (n 91 above) 2.

96 As above.

97 Henrico (n 72 above) 818.

98 Coetzee \& Fourie (n 91 above) 3

99 President of the Republic of South Africa v Modderklip Boerdery 2005 (5) SA 3 (CC) para 36. 
vinidicatio. ${ }^{100}$ This principle could have been used to deny the homeless the only accommodation that they had access to, as the owner of the property had a right under the common law to remove unlawful occupiers from his property. However, the Court chose to interpret this principle in light of the social realities in South Africa.

The Court explained that the apartheid urban planning which excluded African people from urban areas has led to agonising consequences which are still present in the South African society. Poverty and homelessness 'serve as a painful reminder of the chasm that still needs to be bridged before the constitutional ideal to establish a society based on social justice and improved quality of life for all citizens is fully achieved'. ${ }^{10}$ Consequently, the Court held that the state had an obligation to provide adequate accommodation to the unlawful occupiers. ${ }^{102}$ In this way, the law was used to achieve a therapeutic outcome.

The overall objective of therapeutic jurisprudence is the achievement of social justice, namely a dispensation in which legal education transcends the 'narrow confines of the rudimentary blackletter of law' to effectively serve a greater purpose namely, the advancement of social and economic equality as well as the realisation of social justice. ${ }^{103}$

Like Henrico, Quinot also advocates for transformative legal education. He submits that new areas of law such as fundamental rights and judicial review must be accommodated in the law curriculum, and that the curriculum should be adjusted to reflect the new paradigm based on a supreme and justiciable Constitution. ${ }^{104}$ Particular focus should be given to training students in areas that have not seen the same level of constitutional infusion, such as the law of contract, to assess long-established common law rules against the values entrenched in the Constitution. 105

Transformative legal education runs the risk of being a mere paradigm and effectively being lost in translation if not used effectively and optimally. This means that its effectiveness depends on a purposive interpretation of the law and the 'Constitution suffused with the necessary values such as the notion of ubuntu which tease out and animate the provisions of the Bill of Rights in a manner

100 President of the Republic of South Africa $v$ Modderklip Boerdery 2005 (5) SA 3 (CC) para 36.

101 President of the Republic of South Africa v Modderklip Boerdery (n 100 above) para 35

102 President of the Republic of South Africa v Modderklip Boerdery (n 100 above) para 48.

103 Henrico (n 72 above) 825

104 Quinot (n 83 above) 414

105 D Moseneke 'Transformative constitutionalism: Its implications for the law of contract' (2009) 20 (1) Stellenbosch Law Review 3. 
that provides protection, relief and benefit to the disadvantaged of society in the quest to create a more egalitarian dispensation. '106

Inexorably linked to ubuntu, as stated in S v Makwanyane, ${ }^{107}$ are notions of respect for life and human dignity. Ubuntu was earmarked in Makwanyane as 'permeating the Constitution generally ... and specifically fundamental human rights'. ${ }^{108}$ There can be no doubt that ubuntu gives impetus to transformative constitutionalism. It demands one to have regard to the imperatives of the Bill of Rights addressing the advancement of the sense of community and social cohesion. ${ }^{109}$ All responsible role-players in South Africa, not least lawyers from all walks of life, must take responsibility to ensure that the values of the Constitution are not reduced to incantatory or ritual phrases in the Bill of Rights, but are 'swung into action' or activated though 'creative law reform programmes, methods, approaches and strategies that will enhance adaptation' to aligning the society with the precepts of the values and principles of the Bill of Rights. ${ }^{110}$

\section{Conclusion}

Section 29 of the Constitution guarantees everyone the right to further education, which the state, through reasonable measures, must make progressively available and accessible. This article has shown that the State has fallen short of taking reasonable measures to advance legal tertiary education in a number of respects. This failure can largely be attributed to the inequalities bequeathed upon the South African legal education system from the apartheid/colonial era.

The authors opine that the first step to decolonising legal education is a shift in the pedagogy of legal education which requires an infusion of constitutional and African values such as ubuntu, in order to create social awareness amongst law students. The integration of customary law into the LLB curriculum will serve as a stepping stone to the Africanisation of legal education. Furthermore, the harmonisation of transformative legal education, ubuntu and therapeutic jurisprudence can only be achieved when legal education is responsive to the demands of our supreme Constitution and reflective of the society in which we live.

106 Henrico (n 72 above) 837.

107 S v Makwanyane 1995 (3) SA 391 (CC).

108 Henrico (n 72 above) 823.

109 Henrico (n 72 above) 821.

110 As above. 